\title{
Renal hypertrophy in experimental diabetes
}

\section{The activity of the 'de novo' and salvage pathways of protein synthesis}

\author{
Sirilaksana KUNJARA, ${ }^{*} \ddagger$ Steven J. BEARDSLEY $\dagger$ and A. Leslie GREENBAUM $\dagger$ \\ *Department of Biochemistry, Pramongkutklao College of Medicine, Bangkok, Thailand, and + Department of Biochemistry, \\ The University College and Middlesex Hospital Medical School, Windeyer Building, London W1P 6DB, U.K.
}

\begin{abstract}
Measurements were made of the activity of phosphoribosyl pyrophosphate amidotransferase (PPRibP-At, EC 2.4.2.14) and of adenine (APRT, EC 2.4.2.7) and hypoxanthine (HPRT, EC 2.4.2.8) phosphoribosyltransferases, representing the 'de novo' and salvage pathways respectively. $P P$ Rib $P$-At activity increased within 3 days of diabetes, whereas APRT and HPRT increased later. Incorporation of $\left[{ }^{14} \mathrm{C}\right]$ formate and of $\left[8-{ }^{14} \mathrm{C}\right]$ adenine into the nucleic acids of kidney slices showed that formate was incorporated earlier, and to a greater extent, than was adenine. These results indicate that, although the 'de novo' pathway for nucleotide synthesis is the main route in early diabetes, the salvage pathway assumes greater importance at later stages.
\end{abstract}

\section{INTRODUCTION}

The renal hypertrophy that occurs in the early stages of experimental diabetes is associated with an increase in both RNA and DNA [1,2], with an increase in the flux of glucose through the pentose phosphate pathway and the activity of the enzymes of the pathway [3], as well as with a fall in the tissue content of phosphoribosyl pyrophosphate $(P P \operatorname{Rib} P)$ [4]. That the increase in RNA is due to a new synthesis, as opposed to a depressed breakdown, has been established by the work of Cortes and his group, who have infused precursors of purine and pyrimidine nucleotides and measured their incorporation into nucleotides and nucleic acids [5-8].

It has been suggested [4] that the fall in tissue content of $P P \mathrm{Rib} P$, despite an increase in the rate of provision of its immediate precursor, ribose 5-phosphate, reflects a cross-over point in the pathway of $P P R$ Rib $P$ production and utilization consequent on an increased rate of nucleic acid synthesis.

Since the synthesis of nucleic acids involves the phosphoribosylation of purine bases, which can arise from either, or both, of the 'de novo' or salvage pathways, the potential activity of these pathways has been studied by the measurement of the activity of the rate-limiting enzyme of the 'de novo' pathway, phosphoribosyl pyrophosphate amidotransferase (PPRibP-At, EC 2.4.2.14) and of the two phosphoribosylating enzymes of the salvage pathway, adenine phosphoribosyltransferase (APRT, EC 2.4.2.7) and hypoxanthine phosphoribosyltransferase (HPRT, EC 2.4.2.8), which also converts guanine into GMP. Parallel studies of the rates of incorporation of $\left[{ }^{14} \mathrm{C}\right]$ formate and of $\left[8-{ }^{14} \mathrm{C}\right] \mathrm{adenine}$ into nucleic acids have been included to establish whether the relative balance of incorporation via the 'de novo' and salvage pathways is modified in diabetes.

\section{METHODS}

\section{Animals}

Male Wistar rats, with initial body weights in the range 170-190 g, were used. Diabetes was induced by the intravenous injection of streptozotocin $(60 \mathrm{mg} / \mathrm{kg}$ body wt.) to animals as previously described [4], and the animals were killed 3,5 or 14 days later.

\section{Incorporation studies}

Approx. $300 \mathrm{mg}$ of kidney slices was incubated in $5 \mathrm{ml}$ of Eagle's Minimal Essential Medium, containing Earle's Balanced Salt Solution (Gibco; 041-1010) as described by Brosh et al. [9], but supplemented with phosphate to give $10 \mathrm{~mm}$ final concentration. The additions were either $20 \mu \mathrm{Ci}$ of sodium $\left[{ }^{14} \mathrm{C}\right]$ formate $(58 \mathrm{mCi} / \mathrm{mmol})$ or $1 \mu \mathrm{Ci}$ of $\left[8-{ }^{14} \mathrm{C}\right]$ adenine $(53 \mathrm{mCi} / \mathrm{mmol})$ (Amersham International). The glucose concentration was $5 \mathrm{~mm}$, the gas phase was $\mathrm{O}_{2} / \mathrm{CO}_{2}(19: 1)$ and the incubation time was $60 \mathrm{~min}$ at $37^{\circ} \mathrm{C}$. The use of $10 \mathrm{~mm}-\mathrm{P}_{\mathrm{i}}$ in the incubation medium requires some justification, in the light of the activating effect of this ion on $P P$ Rib $P$ synthetase [10] and the fact that it is considerably higher than the physiological concentration. This value was chosen because of the high gradient of $P_{i}$ across the cell membrane and because Planet \& Fox [11] have shown, in erythrocytes, that an external concentration of $10 \mathrm{~mm}$ $P_{1}$ gives an intracellular concentration of $1 \mathrm{mM}$, which more closely approximates to the physiological value.

At the end of the incubation period, the contents of the flask were transferred to a homogenizer tube, and $0.5 \mathrm{ml}$ of $10 \mathrm{M}-\mathrm{HClO}_{4}$ was added. After blending in an UltraTurrax blender (Janke und Kunkel, Stauffen-in-Breisgau, Germany), the whole was centrifuged at $2000 \mathrm{~g}$ for $10 \mathrm{~min}$. The extent of incorporation into nucleic acids was measured essentially as described by Brosh et al. [9].

\section{Enzyme measurements}

(1) Preparation of the tissue extracts. The rats were killed by cervical dislocation and the kidneys rapidly removed. The right kidney was used for incorporation studies as described above, and the left kidney for the preparation of tissue extracts. The tissue suspensions were 1:10 (w/v) homogenates of the whole kidney in

Abbreviations used: PPRibP, phosphoribosyl pyrophosphate; PPRibP-AT, phosphoribosyl pyrophosphate amidotransferase; APRT, adenine phosphoribosyltransferase; HPRT, hypoxanthine phosphoribosyltransferase.

$\ddagger$ To whom reprint requests should be sent, at the London address. 
either $0.29 \mathrm{M}$-sucrose/0.01 M-Tris/HCl, pH 7.0 (PPRibPAt), or 0.25 M-sucrose/0.1 mM-EDTA, pH 7.4 (APRT and HPRT). These homogenates were centrifuged at $12000 \mathrm{~g}$ for $30 \mathrm{~min}$ and the supernatants dialysed against $100 \mathrm{vol}$. of the appropriate homogenizing medium for $1 \mathrm{~h}$ before use in the enzyme assays.

\section{(2) Assay procedures.}

(a) PPRibP-At. The activity of this enzyme was measured as described by Wood \& Seegmiller [12]. The separation of the product, $\left[{ }^{14} \mathrm{C}\right]$ glutamate, from the substrate, $\left[\mathrm{U}-{ }^{14} \mathrm{C}\right]$ glutamine, by adsorption on to DEAEcellulose discs, was as described by Martin [13].

(b) APRT. This was measured by the method of Kizaki \& Sakurada [14], except for the addition of $3 \mathrm{~mm}-$ TTP, as described by Allsop \& Watts [15], to inhibit the action of 5'-nucleotidase (EC 3.1.3.5), as suggested by Gutensohn \& Guroff [16].

(c) HPRT. This enzyme was also measured by the method of Kizaki \& Sakurada [14], but with the addition of $3 \mathrm{mM}$-TTP.

\section{Chemical methods}

(a) Nucleic acids. RNA and DNA were measured on a $\mathrm{HClO}_{4}$ pellet from tissue suspensions prepared as above, after the pellet had been extracted with $80 \%(\mathrm{v} / \mathrm{v})$ ethanol and then hydrolysed with $5 \%$ trichloroacetic acid for $30 \mathrm{~min}$ at $90^{\circ} \mathrm{C}$. RNA was measured by the method of Schneider [17] and DNA by the method of Burton [18].

(b) Protein. Protein was measured in the total tissue homogenate by the method of Lowry et al. [19], with bovine serum albumin (fraction V) as standard.

\section{RESULTS}

The changes in the tissue contents of RNA, DNA and $P P$ Rib $P$ resulting from diabetes are shown in Table 1. The changes in nucleic acid content are in agreement with previous reports $[1,8]$, which show that short-term diabetes (2-5 days) has little effect on the RNA content, but decreases DNA by some $10 \%$. They also agree with the previous report [4] in showing that the kidney growth after the induction of diabetes is accompanied by a fall in $P P$ Rib $P$ content.

\section{Enzyme activities}

In view of the difficulty of finding an equitable basis on which to compare values in a rapidly growing tissue, such as kidney in early diabetes, with one which is essentially in a steady-state relationship to the whole animal, as in untreated adult animals, the results given in Table 2 are presented in three ways: as $\mu \mathrm{mol} / \mathrm{h}$ per $\mathrm{g}$, as $\mu \mathrm{mol} / \mathrm{h}$ per total kidney mass and as $\mu \mathrm{mol} / \mathrm{h}$ per $\mathrm{mg}$ of DNA.

On the first of these bases, there are only small changes in the activity of APRT or HPRT at any time studied, but $P P R i b P$-At activity is raised at all times examined, significantly so at 5 and 14 days. When the results are expressed as activity/mg of DNA, APRT is significantly raised at 5 days, but not at either 3 or 14 days; HPRT is significantly raised at all three stages of diabetes studied, as is PPRibP-At, the latter most markedly at the longer time intervals. Finally, when the results are expressed as activity in the total kidney mass, HPRT and PPRibP-At are increased at all three time intervals, and APRT only

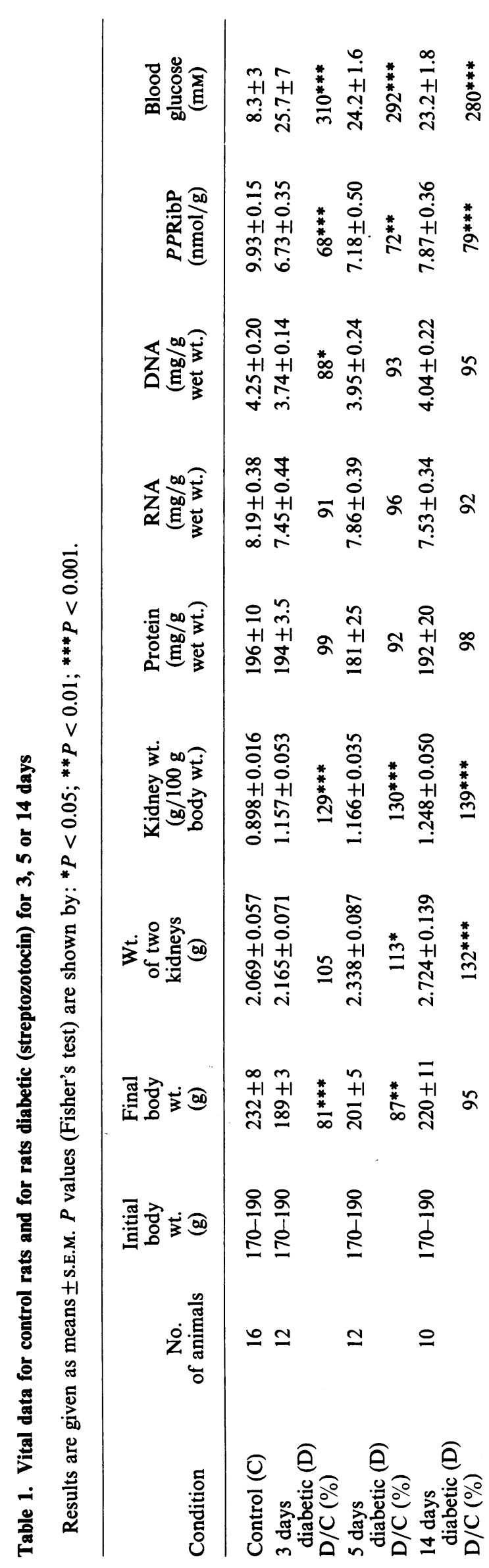




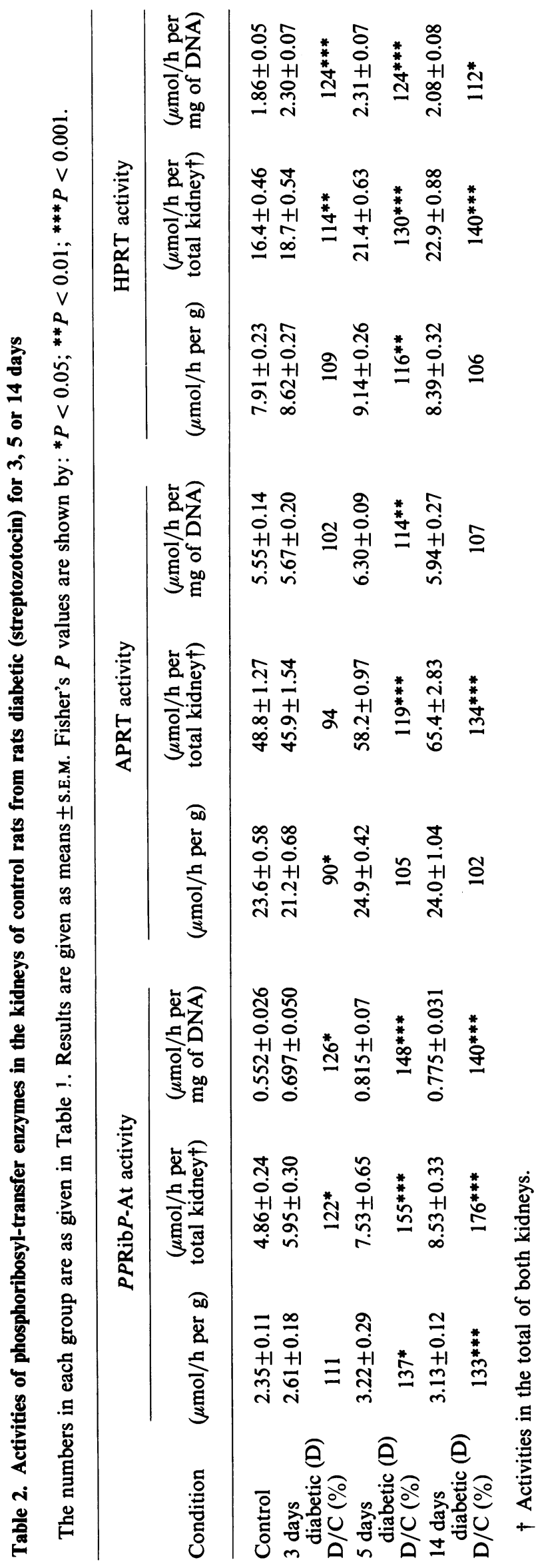

at the two longer times. It is noteworthy that, no matter which mode of presentation is used, the effect of diabetes on PPRibP-At is greater than on the other two enzymes of the salvage pathway, and tends to occur earlier.

\section{Incorporation of $\left[{ }^{14} \mathrm{C}\right]$-formate or -adenine into nucleic acids}

The rate of incorporation of labelled substrates into nucleic acids of normal and diabetic-rat kidneys is shown in Table 3. The incorporation of formate is sharply increased, even at the shortest time studied, and only increases slightly with the length of duration of the diabetes. The increase is apparent on all three modes of expression, and is greater than the rate of increase of either RNA or DNA at each time.

Adenine was incorporated at approximately half the rate of formate, and its rate of incorporation was essentially unchanged by diabetes when the results are expressed on a unit weight basis. Significant increases were observed when the incorporation into the total kidney mass is considered, although the increment of incorporation was appreciably less than that observed when formate was the substrate.

No measurements were made of either hypoxanthine or guanine incorporation, since the changes in the activity of APRT and of HPRT follow very similar courses, and it seemed reasonable to believe that hypoxanthine incorporation would therefore probably parallel the pattern of that shown by adenine.

\section{DISCUSSION}

Increased renal growth in early diabetes is accompanied by an increase renal content of RNA [1,2,6,7]. An increased rate of synthesis of RNA has been proposed as contributing to the accretion of RNA, since the rate of incorporation of labelled orotate and adenine into RNA, measured by continuous infusion in vivo, was elevated in early diabetes [5-7]. Cortes and co-workers [5-8,20] have made detailed studies of the route of pyrimidine synthesis in the rat renal cortex and glomeruli in early diabetes and, in particular, have shown the expansion of the cellular pools of UTP and CTP, which appears to be the result of enhanced synthesis of pyrimidines through the orotate ('de novo') pathway. However, there appears to be less information on the effects of early diabetes on the pathway of purine synthesis or on the changes of the enzymes linked to the 'de novo' and salvage pathways.

The present experiments support the concept that the 'de novo' route of purine synthesis contributes to renal RNA synthesis in streptozotocin-diabetic rats. There is an elevated rate of $\left[{ }^{14} \mathrm{C}\right]$ formate incorporation into the nucleic acids which precedes the marked increase in activity of $P P R$ ib $P$-At, which occurs at 5 days after treatment with streptozotocin. In contrast, parameters linked to the salvage pathway, $\left[{ }^{14} \mathrm{C}\right]$ adenine incorporation and the activities of APRT and HPRT, essentially keep pace with the rate of renal growth and remain constant when expressed per $g$ of kidney cortex. The different patterns of incorporation of $\left[{ }^{14} \mathrm{C}\right]$ formate and of $\left[{ }^{14} \mathrm{C}\right]-$ adenine cannot be ascribed to different pool sizes of adenine, since direct measurement of the renal concentration of adenine showed no significant change in early diabetes. [Adenine concentrations $(\mathrm{nmol} / \mathrm{g})$ were: control, 80.7 $\pm 5.7 ; 3$ days diabetic, $90.9 \pm 5.7 ; 5$ days diabetic, 
Table 3. Incorporation of $\left[1-{ }^{14} \mathrm{C}\right]$ formate or of $\left[8-{ }^{14} \mathrm{C}\right]$ adenine into the nucleic acids of kidney slices taken from control rats and from rats diabetic (streptozotocin) for 3,5 or 14 days

Results are given as means \pm S.E.M., at $37^{\circ} \mathrm{C}$. Fisher's $P$ values are shown by: ${ }^{*} P<0.05 ;{ }^{* *} P<0.01 ;{ }^{* * *} P<0.001$.

\begin{tabular}{|c|c|c|c|c|c|c|}
\hline \multirow[b]{2}{*}{ Condition } & \multicolumn{3}{|c|}{$10^{-3} \times\left[1-{ }^{14} \mathrm{C}\right]$ Formate incorporation (c.p.m./h) } & \multicolumn{3}{|c|}{$\left[8-{ }^{14} \mathrm{C}\right]$ Adenine incorporation $(\mathrm{nmol} / \mathrm{h})$} \\
\hline & $\begin{array}{c}\text { (per g wet } \\
\text { wt.) }\end{array}$ & $\begin{array}{c}\text { (per total } \\
\text { kidney } \dagger \text { ) }\end{array}$ & (per mg of DNA) & $\begin{array}{c}\text { (per g wet } \\
\text { wt.) }\end{array}$ & $\begin{array}{l}\text { (per total } \\
\text { kidney } \dagger \text { ) }\end{array}$ & (per mg of DNA) \\
\hline Control (C) & $424 \pm 39$ & $878 \pm 74$ & $99.7 \pm 9$ & $2.29 \pm 0.08$ & $4.74 \pm 0.17$ & $0.539 \pm 0.018$ \\
\hline $\begin{array}{l}3 \text { days } \\
\text { diabetic }\end{array}$ & $701 \pm 32$ & $1517 \pm 58$ & $188 \pm 4$ & $2.55 \pm 0.08$ & $5.52 \pm 0.17$ & $0.682 \pm 0.021$ \\
\hline $\mathrm{D} / \mathrm{C}(\%)$ & $165^{* * *}$ & $173^{* * *}$ & $188 * * *$ & $111^{*}$ & $116^{* *}$ & $126^{* * *}$ \\
\hline $\begin{array}{l}5 \text { days } \\
\text { diabetic (D) }\end{array}$ & $685 \pm 35$ & $1601 \pm 84$ & $173 \pm 9$ & $2.35 \pm 0.07$ & $5.49 \pm 0.16$ & $0.595 \pm 0.018$ \\
\hline $\mathrm{D} / \mathrm{C}(\%)$ & $162 * * *$ & $182 * * *$ & $174 * * *$ & 103 & $116^{* *}$ & $110^{*}$ \\
\hline $\begin{array}{l}14 \text { days } \\
\text { diabetic (D) }\end{array}$ & $876 \pm 72$ & $2385 \pm 198$ & $215 \pm 18$ & $2.22 \pm 0.08$ & $6.05 \pm 0.22$ & $0.550 \pm 0.020$ \\
\hline $\mathrm{D} / \mathrm{C}(\%)$ & $206^{* * *}$ & $272^{* * *}$ & $215^{* * *}$ & 97 & $128^{* * *}$ & 102 \\
\hline
\end{tabular}

$84.9 \pm 7.5$; six values in each group. We are indebted to Dr. D. Perrett of the Department of Biochemistry, Medical School of St. Bartholomew's Hospital, for these determinations.]

Although the present experiments lend support to a role for both 'de novo' and salvage pathways in the increased RNA of the kidney in experimental diabetes, they do not provide data on the relative contributions of the two routes. Factors in favour of an important role for the salvage route are: the higher absolute activities of APRT and HPRT relative to $P P R$ ibP-At, and the increased adenine incorporation observed in the experiments in vivo by Cortes et al. [5]. Insofar as the data in Table 2 can be taken as indicative of the rates of the two pathways, it may be noted that the rise in activity of the salvage pathway follows that of the 'de novo' pathway, and it is tempting to suggest that, as diabetes develops, the salvage pathway assumes greater prominence as the substrates for the pathway, i.e. adenine and guanine, become available as a result of the increased rate of degradation of muscle RNA which occurs some 2-4 days after the induction of diabetes [21]. It is probably significant that the kidney has a notably high PPRibPAt/HPRT activity ratio [16], also indicative of the importance of the 'de novo' pathway in this tissue.

The present results, showing aspects relating to increased biosynthesis of purine nucleotides, taken in conjunction with the extensive evidence for elevated pyrimidine synthesis de novo, support the hypothesis previously advanced that the fall in renal $P P R \mathrm{Rib} P$ in early diabetes is a resultant effect of increased utilization [4].

This work was supported by grants from the British Diabetic Association, the Basil Samuel Charitable Trust and the Association for International Cancer Research. S.K. was supported by the National Kidney Research Fund.

\section{REFERENCES}

1. Seyer-Hansen, K. (1976) Clin. Sci. Mol. Med. 51, 551-555

2. Seyer-Hansen, K. (1983) Kidney Int. 23, 643-646

3. Steer, K. A., Sochor, M. \& McLean, P. (1985) Diabetes 34, 485-490

4. Kunjara, S., Sochor, M., Adeoya, A., McLean, P. \& Greenbaum, A. L. (1986) Biochem. J. 234, 579-585

5. Cortes, P., Verghese, C. P., Venkatachalam, K. K., Shoenberger, A. M. \& Levin, N. W. (1980) Am. J. Physiol. 238, E341-E348

6. Cortes, P., Levin, N. W., Dumler, F., Rubenstein, A. H., Verghese, C. P. \& Venkatachalam, K. K. (1980) Am. J. Physiol. 238, E349-E357

7. Cortes, P., Dumler, F. Venkatachalam, K. K. \& Levin, N. W. (1983) Miner. Electrolyte Metab. 9, 306-316

8. Cortes, P., Dumler, F., Goldman, J. \& Levin, N. W. (1987) Diabetes 36, 80-87

9. Brosh, S., Boer, P. \& Kupfer, B. (1976) J. Clin. Invest. 50, 289-297

10. Becker, M. A., Raivio, K. O. \& Seegmiller, J. E. (1979) Adv. Enzymol. 49, 281-306

11. Planet, G. \& Fox, I. H. (1976) J. Biol. Chem. 251, 5839-5844

12. Wood, A. W. \& Seegmiller, J. E. (1973) J. Biol. Chem. 248, 138-143

13. Martin, D. W., Jr. (1972) Anal. Biochem. 46, 239-243

14. Kizaki, H. \& Sakurada, T. (1976) Anal. Biochem. 72, 49-56

15. Allsop, J. \& Watts, R. W. E. (1980) J. Neurol. Sci. 46, 221-232

16. Gutensohn, W. \& Guroff, G. (1972) J. Neurochem. 19, 2139-2150

17. Schneider, W. C. (1957) Methods Enzymol. 3, 680-684

18. Burton, K. (1956) Biochem. J. 62, 315-323

19. Lowry, O. H., Rosebrough, N. J., Farr, A. L. \& Randall, R. J. (1951) J. Biol. Chem. 193, 265-275

20. Cortes, P., Dumler, F. \& Levin, N. W. (1986) Kidney Int. 30, 27-34

21. Ashford, A. J. \& Pain, V. M. (1986) J. Biol. Chem. 261, 4059-4965 